Anna Goljan-Geremek', Michał Bednarek', Monika Franczuk', Elżbieta Puścińska', Adam Nowiński', Monika Czystowska', Dariusz Kamiński', Damian Korzybski', Anna Stokłosa', Anna Kowalska', Emil Wojda ${ }^{2}$, Paweł Śliwiński ${ }^{2}$, Barbara Burakowska ${ }^{3}$, Jakub Ptak ${ }^{3}$, Inga Barańska ${ }^{3}$, Alicja Drygalska ${ }^{3}$, Grzegorz Małek ${ }^{3}$, Iwona Bestry ${ }^{3}$, Stefan Wesołowski ${ }^{4}$, Marek Kram ${ }^{5}$, Dorota Górecka ${ }^{1}$

${ }^{1} 2^{\text {nd }}$ Department of Respiratory Medicine of the National Research Institute of Tuberculosis and Lung Diseases, Warsaw Head: Prof. D. Górecka, MD, PhD

${ }^{2} 4^{\text {th }}$ Department of Respiratory Medicine of the National Research Institute of Tuberculosis and Lung Diseases, Warsaw Head: Prof. P. Śliwiński, MD, PhD

${ }^{3}$ Radiology Department of the National Research Institute of Tuberculosis and Lung Diseases, Warsaw

Head: I. Bestry, MD

${ }^{4}$ Department of Physiopathology of the Respiratory System of the National Research Institute of Tuberculosis and Lung Diseases, Warsaw Head: Prof. S. Wesotowski, MD, PhD

${ }^{5}$ Physiotherapy Department of the Respiratory System of the National Research Institute of Tuberculosis and Lung Diseases, Warsaw Head: M. Kram

\title{
Methotrexate as a single agent for treating pulmonary sarcoidosis: a single centre real-life prospective study
}

\author{
Metotreksat w monoterapii w leczeniu sarkoidozy płucnej: doświadczenia własne \\ This work was carried out within the statutory activity of the National Research Institute of Tuberculosis and Lung Diseases, Warsaw. \\ Protocol approval number by the local Ethical Committee: KE-31/2004
}

\section{Abstract}

Introduction: The first-line therapy in chronic sarcoidosis, according to WASOG/ATS/ERS recommendations, is GCS. This therapy is associated with significant adverse effects and finally does not alter the natural history of the disease. The objective of our study was to evaluate the efficacy and safety of monotherapy with MTX, as an alternative to GCS, in progressive pulmonary sarcoidosis. Material and methods: An open prospective real-life, single-centre trial was performed on 50 patients with biopsy proven sarcoidosis, $28 \mathrm{M}$ and $22 \mathrm{~F}$, mean age $45.55 \pm 8.9$ years. The average duration of disease before MTX therapy was $12.34 \pm 20.49$ years, GCS therapy in the past was applied in 41 patients. All patients received MTX (10 mg or $15 \mathrm{mg}$ weekly) between 2004 and 2013 because of chronic progressive pulmonary sarcoidosis. Therapy was planned for 24 months. Patients underwent regular clinical evaluation, pulmonary function assessment, exercise ability testing (6MWT), and chest radiography for therapy effectiveness every six months and side effects monitoring every $4-6$ weeks. Forty-nine patients were included for statistical analysis of treatment efficacy. They were retrospectively allocated to "MTX responder" group if an improvement of $10 \%$ of FEV 1 , FVC, TLC, or $15 \%$ of DLCO from the initial value was documented for at least one parameter or "non-responders" if the patient did not meet the above-mentioned criteria. Results: Duration of treatment ranged from 6 to 24 months, mean time $60.75 \pm 34.1$ weeks. For the whole cohort significant improvement after MTX therapy was observed for minimal $\mathrm{SaO}_{2}(\%)(p=0.043)$ and for decrease of $\Delta \mathrm{SaO}_{2}(\%)(p=0.048)$ in six-minute walk test. The results were significantly better for patients treated with $15 \mathrm{mg}$ than for those treated with $10 \mathrm{mg}$ weekly and for those who obtained a greater total amount of MTX during therapy. Significant difference of DLCO\%pred was observed after six months of MTX therapy between groups treated $15 \mathrm{mg}$ vs $10 \mathrm{mg}$ weekly $(73.27 \pm 12.7 \%$ vs. $63.15 \pm 16.4 \%$, $p=0.03$ ). Twenty-five patients (55\%) met the criteria of "MTX responders" group. Patients who responded well to treatment had significantly lower TLC and FVC initial values comparing to "MTX non-responders". After treatment the only significant difference in PFT between groups was noted for DLCO\%pred. Eleven patients (22\%) stopped the treatment due to adverse events of MTX, mild hepatic abnormalities were observed in ten patients $(20 \%)$, and concomitant infection was found in four patients. There were no patients with a fatal outcome.

Address for correspondence: Anna Goljan Geremek, MD, 2 nd Department of Respiratory Medicine of the National Research Institute of Tuberculosis and Lung Diseases, Płocka 26 ,

01-138 Warsaw, Poland, e-mail: a.goljan@gmail.com

DOI: 10.5603/PiAP.2014.0069

Praca wpłynęła do Redakcji: 30.07.2014 r.

Copyright (C) 2014 PTChP

ISSN 0867-7077 
Conclusions: MTX as a single agent in the treatment of sarcoidosis has proved to be a safe and effective steroid alternative. Selected patients with chronic pulmonary sarcoidosis experience definite PFT improvements after MTX treatment. There is need to search for predictors of MTX treatment effectiveness.

Key words: methotrexate, sarcoidosis, PFT, treatment

Pneumonol. Alergol. Pol. 2014; 82: 519-533

\section{Streszczenie}

Wstęp: Kortykosteroidoterapia jest według aktualnych wytycznych WASOG/ATS/ERS leczeniem pierwszego rzutu u chorych na przewlekłą sarkoidozę. Jest to leczenie obarczone wysokim ryzykiem wystąpienia objawów ubocznych, które pogarszają rokowanie odległe. Jednocześnie nie ma pewności, że glikokortykosteroidy (GKS) modyfikują naturalny przebieg choroby. Celem pracy była ocena skuteczności i bezpieczeństwa leczenia metotreksatem (MTX) w monoterapii chorych na przewlekłą sarkoidozę płucną. Materiał i metody: Do leczenia zakwalifikowano 50 chorych na przewlekłą sarkoidozę płuc potwierdzoną badaniem histopatologicznym, 28M i 22K, w średnim wieku 45,55 \pm 8,9 roku, ze średnim czasem trwania choroby do włączenia MTX wynoszącym $12,34 \pm 20,49$ roku. W latach 2004-2013 zastosowano u tych chorych MTX w monoterapii, w dawkach $10 \mathrm{mg}$ lub $15 \mathrm{mg}$ tygodniowo. Czterdziestu jeden pacjentów było wcześniej leczonych GKS. Wszyscy mieli wykonywane badania laboratoryjne, czynnościowe oraz radiologiczne układu oddechowego przed rozpoczęciem leczenia i w trakcie monitorowania skuteczności (co 6 miesięcy) oraz bezpieczeństwa terapii (co 4-6 tygodni). Do analizy statystycznej oceniającej skuteczność leczenia włączono 49 chorych. Na podstawie retrospektywnej analizy wyników badań czynnościowych (FEV 1 , FVC, TLC, DLCO) wykonanych na zakończenie leczenia, w porównaniu z wynikami badań czynności płuc przed podaniem MTX (poprawa o 10\% w zakresie FEV TLC lub o 15\% DLCO), wyodrębniono chorych, u których stwierdzono obiektywną, istotną poprawę wskaźników czynnościowych płuc po leczeniu (grupa „z obiektywną poprawą po leczeniu”).

Wyniki: Okres leczenia wynosił od 6 do 24 miesięcy, średnio $60,75 \pm 34,1$ tygodnia. W całej grupie istotną poprawę po leczeniu MTX stwierdzono dla $\mathrm{SaO}_{2}$ min $(\%)(p=0,043)$ oraz dla $\Delta \mathrm{SaO}_{2}(\%)(p=0,048)$ ocenianej w czasie testu 6-minutowego marszu. Istotnie lepsze efekty leczenia uzyskano w grupie otrzymującej $15 \mathrm{mg}$ MTX tygodniowo oraz u chorych, którzy otrzymali sumarycznie większą dawkę MTX podczas całej kuracji. Istotną statystycznie różnicę po 6 miesiącach leczenia między grupami leczonymi $15 \mathrm{mg} \mathrm{v}$. $10 \mathrm{mg}$ tygodniowo stwierdzono dla DLCO\% pred (73,27 $\pm 12,7$ v. 63,15 $\pm 16,4 ; p=0,03)$. Obiektywną poprawę po leczeniu stwierdzono u 25 pacjentów (55\%). Chorzy, u których stwierdzono obiektywną poprawę po MTX, mieli wyjściowo istotnie niższe wartości TLC i FVC w porównaniu z grupą bez poprawy po MTX. Po zakończeniu leczenia jedyną istotnie statystycznie różnicę między obiema grupami obserwowano w zakresie DLCO. U 11 chorych (22\%) przerwano leczenie z powodu objawów ubocznych. Najczęściej obserwowanym objawem ubocznym leczenia był wzrost wskaźników wątrobowych (10 chorych, 20\%). U 4 osób stwierdzono powikłania infekcyjne. U żadnego chorego nie stwierdzono powikłań zagrażających życiu.

Wnioski: Metotreksat w monoterapii może być bezpieczną i skuteczną alternatywą dla steroidów. U części chorych należy spodziewać się obiektywnej poprawy czynności płuc po leczeniu. Wskazane są dalsze badania w poszukiwaniu wskaźników prognozujących skuteczność leczenia.

Słowa kluczowe: metotreksat, sarkoidoza, badania czynnościowe płuc, leczenie

Pneumonol. Alergol. Pol. 2014; 82: 518-533

\section{Introduction}

Low-dose methotrexate (MTX) therapy has been used to treat a variety of chronic inflammatory diseases and has proved to be a cornerstone therapy [1-3]. Few studies have discussed the efficacy of such treatment in sarcoidosis. Patients with symptomatic sarcoidosis are usually treated with glucocorticosteroids (GCS). However, the GCS therapy is associated with significant adverse effects and finally does not alter the natural history of the disease $[4,5]$.

Data supporting the use of MTX as a single therapy for pulmonary sarcoidosis are very limited. In most cases MTX was used as a steroid-sparing agent [6-9]. There are case reports in literature of patients with symptomatic sarcoidosis, being refractory to steroids, and successfully treated with low-dose methotrexate without severe adverse effects. In most published cases extrapulmonary sarcoidosis was the target of therapy. These findings suggest that low-dose methotrexate therapy may be a useful alternative treatment for sarcoidosis although the proper use and efficacy of MTX as a single agent remain unclear.

Recently published recommendations for use of methotrexate in sarcoidosis were based on the results of one randomised controlled trial (RCT), several observational case series (10 case series involving more than 10 patients, and 32 case reports involving fewer than 10 pa- 
tients) and expert opinions [10]. According to the WASOG Task Force, steroids are the first-line therapy in sarcoidosis [11]. The indications for MTX in sarcoidosis consist of its use as a second-line treatment option in steroid-refractory cases, in the presence of steroid-associated adverse effects, or as a steroid-sparing agent. As a first-line treatment option, MTX is indicated as an MTX/ /steroid combination therapy or monotherapy in exceptional situations [10].

In this context the studies looking into the efficacy and safety of MTX as a single agent in treating chronic progressive sarcoidosis are highly anticipated and valuable. The objective of the present study was to evaluate the efficacy and safety of monotherapy with MTX in chronic pulmonary sarcoidosis patients.

\section{Material and methods}

\section{Study design}

The study was designed as prospective single-centre cohort project. The aim of the study was to assess the effectiveness and safety of MTX, given as a single agent for chronic progressive pulmonary sarcoidosis. Patients were recruited from those seen by the authors for symptomatic, chronic sarcoidosis [11] at the Respiratory Department of the National Tuberculosis and Lung Diseases Research Institute between January 2004 and December 2013. MTX was proposed to patients who were previously unsuccessfully treated by systemic corticosteroids and, as a first line therapy, to patients who were not treated by GCS due to contraindications for such treatment or due to refusal of the steroid therapy because of possible adverse effects (AE). The decision to begin systemic methotrexate therapy in each case was taken collectively by a team of investigators (the same clinicians for all of the patients) and approved by the Head of the Pulmonary Department. All patients gave written informed consent of a protocol approved by the local Ethical Committee.

\section{Patients}

Inclusion criteria:

- adult patients (over 18 years old) of either gender, with the diagnosis of sarcoidosis confirmed by the biopsy, clinical picture of the disease compatible with WASOG/ATS/ /ERS criteria [11],

- documented chronic, progressive stage II or III pulmonary sarcoidosis according to WASOG/ /ATS/ERS criteria [11, 12],
- patients with pulmonary indication for systemic treatment and: steroid refractory sarcoidosis or steroid resistant disease, or presence of steroid-associated adverse effects with contraindication for steroid therapy or patient's wish to start treatment with alternative to steroid therapy.

\section{Exclusion criteria:}

- extrapulmonary sarcoidosis that required immediate treatment with oral corticosteroids (e.g. cardiac sarcoidosis),

- patients receiving treatment with corticosteroids for some other reason,

- patients with contraindications for MTX,

- pregnant, lactating women or those planning pregnancy,

- patients with other specific, poorly controlled diseases,

- patients who did not sign the informed consent form.

The therapeutic decision was based on clinical criteria [11-13]: the presence of disabling or distressing symptoms of sarcoidosis (dyspnoea, cough, wheezing, chest pain) with decreased exercise tolerance confirmed by six-minute walking test (6MWT) and:

- a $10 \%$ or more decline of forced expiratory volume in one second $\left(\mathrm{FEV}_{1}\right)$, forced vital capacity (FVC), total lung capacity (TLC), or a $15 \%$ or more decline of diffusing capacity (DLCO) for two consecutive measurements prior to enrolment, or severe impairment of pulmonary function test (PFT) at the initial examination, or

- the presence of progressive pulmonary, parenchymal disease with signs of pulmonary fibrosis, confirmed by chest X-ray (CXR) and high-resolution computed tomography (HRCT) and documented by retrospective analysis of the imaging records by two independent radiologists (BB, IB).

\section{Protocol}

The protocol of the study is shown in the flow chart (Fig. 1). Prior to the administration of MTX (visit 0 - initial evaluation, recruitment) all patients were followed-up for at least six months with no therapy. At the baseline visit (visit 1) medical records were collected for: BMI, previous treatment, disease duration from establishing the diagnosis of sarcoidosis to the baseline visit. Then the indications for the treatment with MTX because of pulmonary sarcoidosis were confirmed. Patients received 


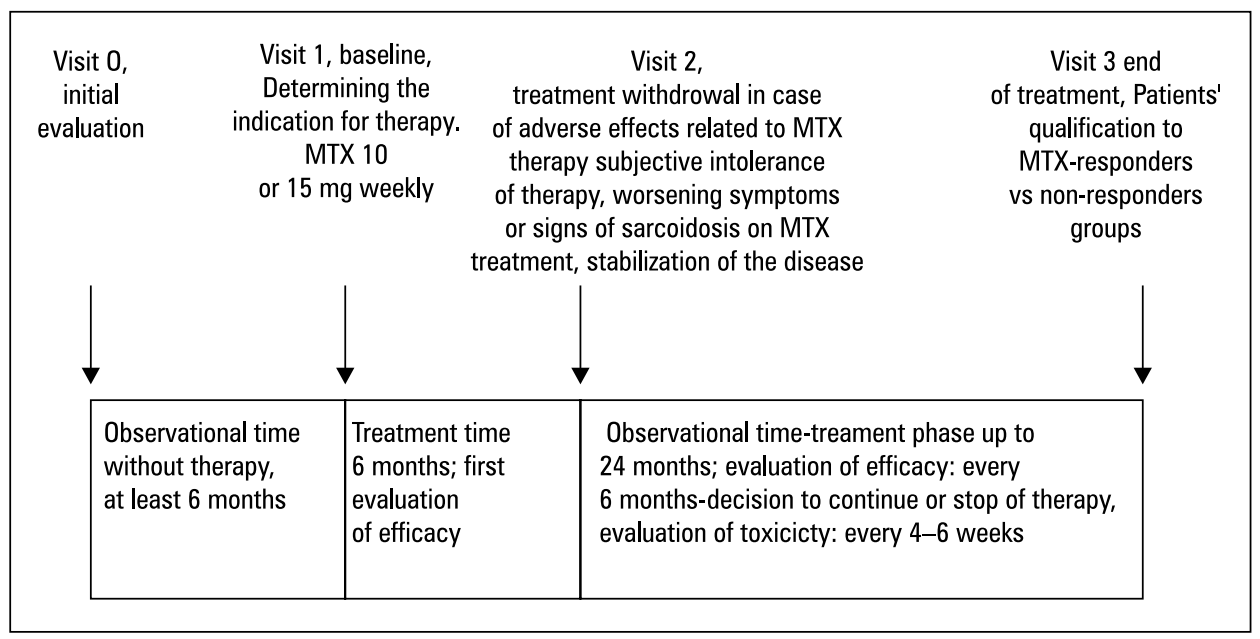

Figure 1. Flow chart study design

methotrexate according to our own protocol. The therapy was planned for 24 months. Initial standard dose was set at $10 \mathrm{mg}$ per week. In individual cases a higher dose of $15 \mathrm{mg}$ weekly was proposed, according to the recommendations adapted from rheumatic diseases and from sarcoidosis experts' opinions [12-14]. Additionally, all patients took $5 \mathrm{mg}$ folic acid every day (excluding the day of MTX administration). Toxicity of therapy was assessed every $4-6$ weeks by the treating physician during regular medical visits, and additional diagnostic procedures were performed if necessary.

Routine laboratory tests (total blood counts, hepatic and renal function tests, electrolytes) were taken at recruitment (visit 0), at baseline visit-initiation of therapy (visit 1), and during observational time to check for MTX adverse effects (every 4-6 weeks). All the CT scans that were performed at the initiation of treatment were reviewed for the presence of fibrosis, bronchiectasis, and ground glass opacities. Pulmonary function (PF) was assessed by spirometry, plethysmography, and diffusion capacity of the lung. Measured parameters were presented as percentage of predicted value. The measurements of $\mathrm{FEV}_{1}, \mathrm{FVC}$, TLC, DLCO, $\mathrm{FEV}_{1} / \mathrm{FVC}$, and six-minute walking test (6MWT) were performed at recruitment, at baseline visit 1 , after six months of treatment (visit 2), and at medication withdrawal. All spirometric and plethysmographic measurements were performed using the Jaeger Master Screen Body, version 4.65, according to ERS/ATS 2005 statement. The exercise capacity was measured by 6MWT performed on a treadmill. Heart rate (HR), blood pressure (BP), and pulse oximetry with maximal (at rest) and minimal (during exercise) oxygen saturation $\left(\mathrm{SaO}_{2} \mathrm{~min}\right)$ were recorded, as well as the walking distance (6MWD) and the dyspnoea Borg score before and after exercise. The parameters taken into account were as follows: dyspnoea Borg score, 6MWD, minimal saturation during exercise $\left(\mathrm{SaO}_{2} \mathrm{~min}\right)$, and degree of desaturation during exercise $\left(\Delta \mathrm{SaO}_{2}\right)$.

The involvement of extrapulmonary sites was diagnosed according to criteria proposed in the ACCESS [15]. The longitudinal and transverse dimensions of spleen and liver (right and left lobes) were measured by ultrasound at baseline, at visit 1, and at MTX withdrawal. Then the results were compared to search for possible toxicity of therapy. In patients with abnormal laboratory findings at baseline visit, suggesting liver disease, hepatic biopsy prior to treatment was performed and a gastroenterologist opinion was obtained to exclude the contraindications for MTX.

The routine check for latent or active tuberculosis (TB) infection in our cohort before starting MTX therapy included tuberculin test, and sputum and bronchoalveolar lavage (BAL) fluid cultures for acid fast bacilli (AFB) and were repeated during observational time in case of signs or symptoms of respiratory infection.

All infections were reported as adverse events (AE) of MTX, even those that did not require antibiotic treatment.

\section{Materials}

At the initial visit (visit 0) 76 patients were recruited to the study. At baseline visit (visit 1) 50 patients met the inclusion criteria and did not meet the exclusion criteria and were eligible to receive MTX therapy. Finally the material consisted 
of 28 men (57\%) and 22 women (43\%) in the age range 35 to 62 years. For the statistical analysis 49 patients were included (one patient was not included due to non-compliance). The median disease duration, from establishing the diagnosis to starting MTX therapy, was 12.34 years (range from 1 year to 26 years).

Sarcoidosis in stage II was diagnosed in 28 patients, and 22 were in stage III. In all cases sarcoidosis was proven by histological examination. All patients had signs of fibrosis confirmed by lung HRCT scans. In 17 patients (37\%) bronchiectases were present as a consequence of advanced fibrosing process in the lungs. In eight patients $(18 \%)$ ground glass opacities were described in lung CT scans.

Extrathoracic sarcoidosis was diagnosed in 37 patients (74\%): spleen involvement was observed in 19 cases, lymph nodes involvement in 18 cases, skin in 10 cases, and hepatic sarcoidosis in 9 cases. Liver biopsy was performed in 12 cases, and 8 cases revealed sarcoid granulomas. One case of HCV infection was diagnosed and the patient received an MTX regimen of $10 \mathrm{mg}$ weekly after gastroenterologist approval.

In 41 cases (82\%) MTX was administered to patients who were previously treated by systemic corticosteroids because of progressive pulmonary sarcoidosis. Twenty patients received one course of GCS treatment (two years of therapy), 21 patients received more than one course (total duration of GCS therapy $>2$ years) and were refractory after GCS withdrawal. MTX was proposed to 17 patients who did not experience any significant improvement after GCS, and to 24 patients who were responsive to GCS but experienced unacceptable AE after GCS therapy $(\mathrm{N}=10)$ or refused to be treated with GCS again $(\mathrm{N}=14)$. The mean time between the end of GCS therapy and institu- tion of MTX therapy was $18.6 \pm 18.3$ months (range 6-85 months). In nine cases MTX (18\%) was proposed as a first-line therapy in patients who refused the steroid therapy because of potential $\mathrm{AE}(\mathrm{N}=5 ; 10 \%)$ or because of contraindication for such treatment $(\mathrm{N}=4 ; 8 \%)$. Before starting the MTX therapy, significant deterioration in PFT was observed in 41 patients (82\%). In $5(10 \%)$ patients the initial PFTs were abnormal (at visit 0 ), with no changes during six months of observation before starting MTX therapy, but radiological progression was observed between visit 0 and visit 1 , accompanied by disabling (according to subjective patients' opinion), symptoms. The PFT results at different time intervals, showing the significant function deterioration that justified the indications for MTX therapy, are represented in Table 1 and Figure 2.

\section{Evaluation of effectiveness of therapy}

Patients were classified after treatment as "responders" and "non-responders" to MTX, based on four measures of PFT (FEV ${ }_{1}, \mathrm{FVC}$, TLC, DLCO) and CXR. Additionally, 6MWT parameters $\left(\mathrm{SaO}_{2} \mathrm{~min}, \Delta \mathrm{SaO}_{2}\right.$, and dyspnoea level) were assessed. A $10 \%$ improvement of $\mathrm{FEV}_{1}$, or FVC, or TLC or 15\% of DLCO from the initial value (before treatment) compared to values at the time of MTX termination for at least one parameter classified a patient as an "MTX responder". Patients with deterioration of PFT parameters superior to $10 \%$ in $\mathrm{FEV}_{1}, \mathrm{FVC}$, TLC or $15 \%$ of DLCO, and those who had no changes in the PFT parameters during treatment, were classified as "MTX non-responders". First analysis of effectiveness was made at the visit occurring six months (visit 2) after initiation of therapy as it was proven by other authors that one can expect the MTX effectiveness by six months of treatment $[7,8,16]$.

Table 1. Pulmonary function test (PFT) in whole cohort. Significant deterioration of FEV , FVC, and DLCO between visit 0 and visit 1 as an indication for MTX therapy is shown

\begin{tabular}{lcccc}
\hline Variable & $\begin{array}{c}\mathbf{6} \text { months before therapy, } \\
\text { visit 0 } \\
\mathbf{N}=\mathbf{4 6}\end{array}$ & $\begin{array}{c}\text { Baseline: on MTX initia- } \\
\text { tion, visit } \\
\mathbf{N}=\mathbf{4 9}\end{array}$ & $\begin{array}{c}\text { 6-month interim, visit 2 } \\
\mathbf{N}=\mathbf{4 8}\end{array}$ & $\begin{array}{c}\text { End of treatment**, visit 3 } \\
\mathbf{N}=\mathbf{4 9}\end{array}$ \\
Mean \pm SD & $78.07 \pm 17.9^{\mathrm{a}, \mathrm{b}, \mathrm{c}}$ & $66.52 \pm 15.6^{\mathrm{a}}$ & $66.95 \pm 15.8^{\mathrm{b}}$ & $67.48 \pm 16.9^{\mathrm{c}}$ \\
\hline DLCO \%pred & $90.28 \pm 14.0$ & $84.97 \pm 18.2$ & $89.74 \pm 18.0$ & $89.65 \pm 17.4$ \\
TLC \% pred & $90.67 \pm 18.5^{\mathrm{c}}$ & $79.16 \pm 16.1^{\mathrm{c}}$ & $84.46 \pm 19.1$ & $85.84 \pm 19.2$ \\
FVC \%pred & $83.89 \pm 20.3^{\mathrm{b}, \mathrm{c}}$ & $70.39 \pm 19.5^{\mathrm{b}}$ & $72.87 \pm 20.6^{\mathrm{c}}$ & $73.45 \pm 21.0$ \\
FEV & $\%$ pred &
\end{tabular}

Post-hoc Tukey's RIR test, $\mathrm{p}$ significance: ${ }^{\mathrm{a}}<0.005,{ }^{\mathrm{b}}<0.01,{ }^{\mathrm{c}}<0.05$; abbreviations in the text

*in one patient the PFTs were performed in a different Pathophysiological Department, not included in the statistical analysis; **all patients were included, independently of treatment duration 


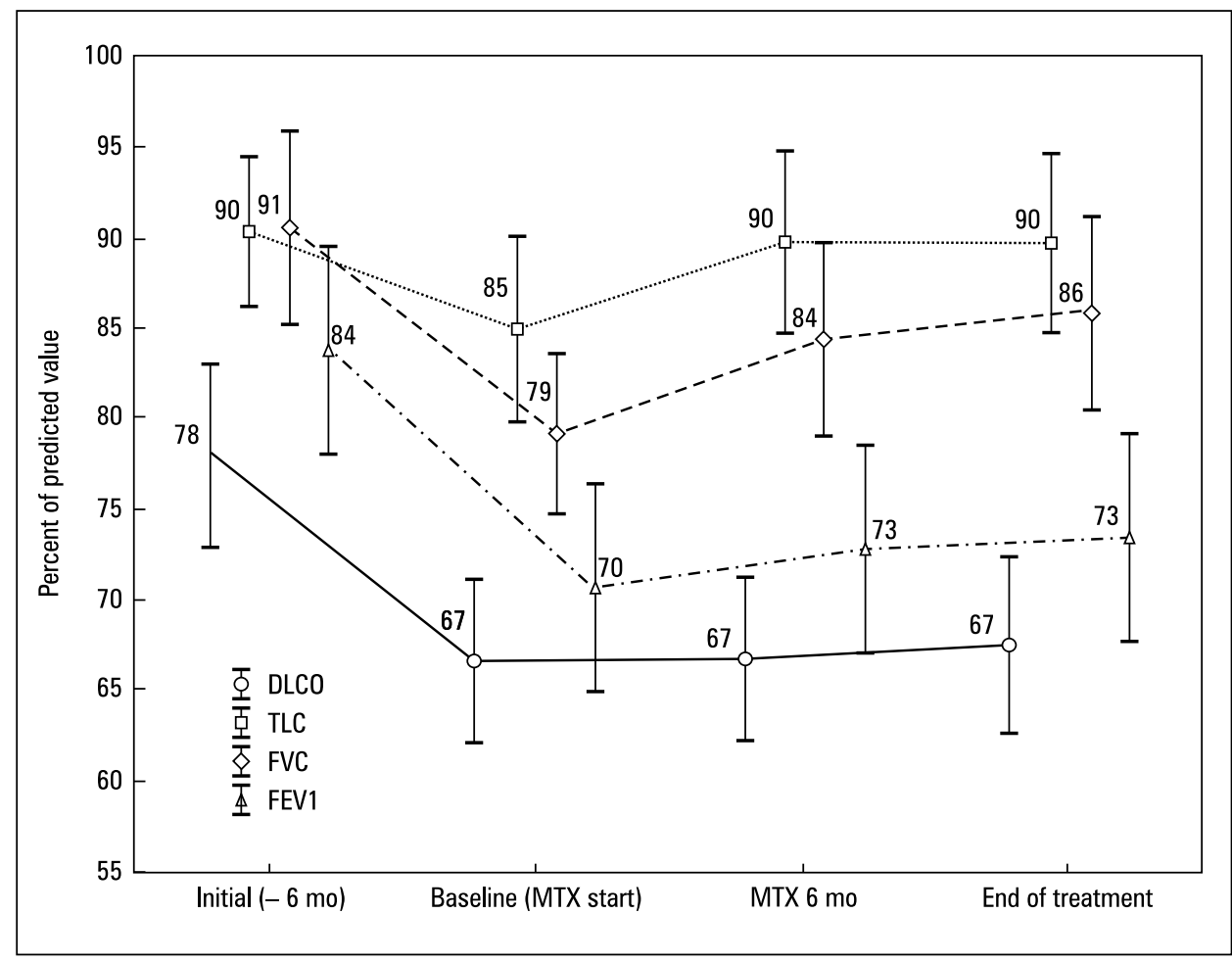

Figure 2. The comparison of pulmonary function test (PFT) in whole cohort, starting from the recruitment (visit 0), than baseline (visit 1 ), after 6 months of therapy (visit 2) and at the MTX withdrawal. Significant deterioration of FEV ${ }_{1}, F V C$, DLCO between visit 0 and visit 1 as an indication for MTX therapy is shown

In the absence of deterioration or unacceptable side effects, patients continued receiving therapy with MTX, with the intention of maintaining treatment for 24 months. Reassessment of efficacy of MTX was performed every six months. The therapy was terminated prematurely (before the planned 24 months) in patients who developed adverse effects related to MTX therapy, reported subjective intolerance of therapy, presented worsening of symptoms, or deterioration of PFT or radiological picture due to sarcoidosis on MTX treatment. It was also terminated if the patient had shown no evidence of improvement and remained consistently stable for two consecutive visits (Fig. 3). To determine the number of patients responsive to therapy all cases were included, independently of the duration of treatment.

\section{Statistical analysis}

Statistical analyses were performed using Statistica 10 software (StatSoft, Inc., USA, 2011) and MedCalc Statistical Software version 13.3.1 (MedCalc Software bvba, Ostend, Belgium, 2014). Tests were considered significant when $\mathrm{p}<0.05$. Data distribution was analysed using the Kolmogorov-Smirnov test with Lilliefors correction. Quantitative data were described using mean \pm SD. If a variable demonstrated normal distribu- tion and homogenous variance, $\mathrm{t}$ test was applied. Between-group characteristics were described using t tests for paired or independent variables. For nonparametric data comparisons between groups Mann-Whitney U test was used for independent samples and Wilcoxon test for paired samples. Categorised, qualitative, between-group analyses were performed using the Pearson $\chi^{2}$ test with appropriate corrections for N.

\section{Results}

Thirty-one (66\%) patients received MTX at dose of $10 \mathrm{mg}$ weekly and $18(36 \%)$ patients at $15 \mathrm{mg}$ weekly (Table 2). In the group treated with $10 \mathrm{mg}$ weekly, 18 patients (54\%) were classified to the "non-responders" group. In the group treated with $15 \mathrm{mg}$ weekly, only six patients (35\%) were classified as "non-responders". In the group of patients treated with $15 \mathrm{mg}$ weekly, 7/18 (39\%) patients completed 24 months regiment (vs. 7/31, $22 \%$, patients from the 10 mg-weekly group). Patients treated with $15 \mathrm{mg}$ weekly had significantly more important amelioration (of $>10 \%$ ) of DLCO compared to patients receiving $10 \mathrm{mg}$ weekly (Tab. 2).

The mean duration of therapy for the whole group was $60.74 \pm 34.1$ weeks. Fourteen patients (28\%) completed the 24-month MTX treatment. 


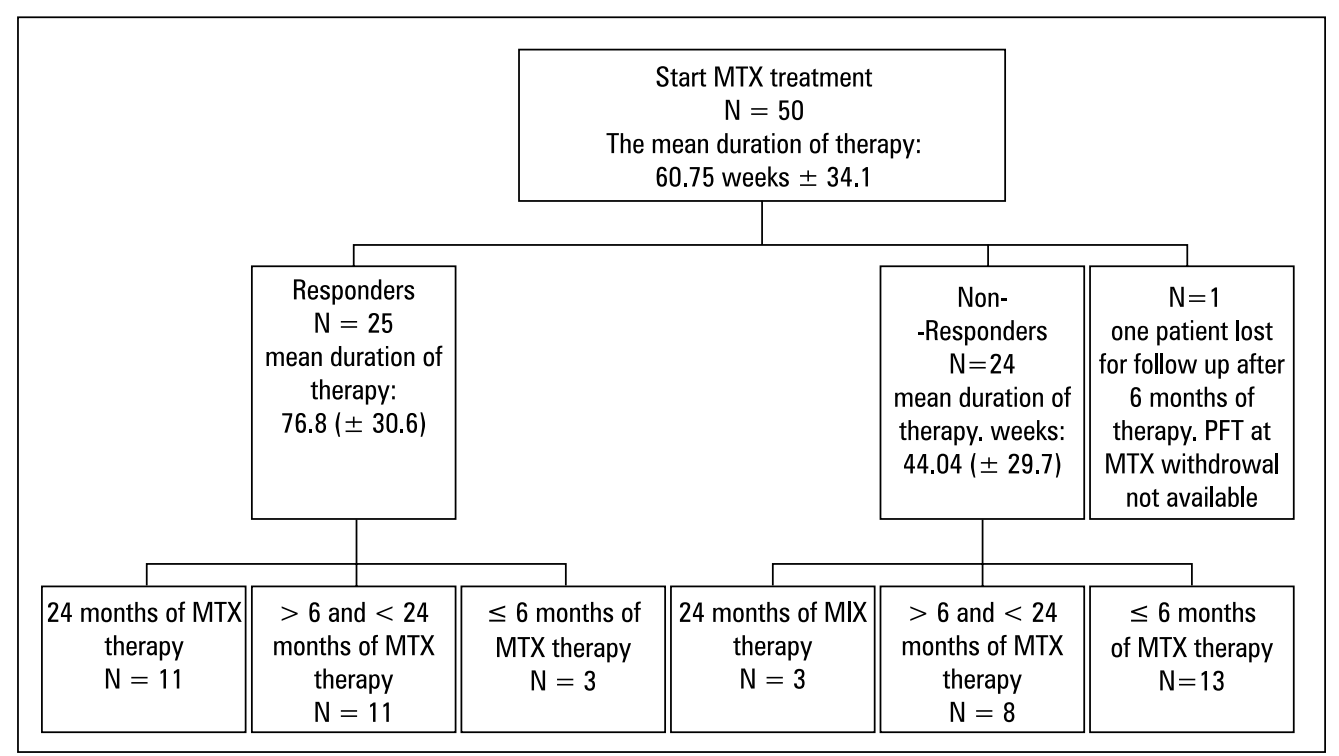

Figure 3. Study flow of patients who received methotrexate (MTX) during 2 year follow up from start of treatment. 49 patients are still in follow up.

Table 2. The dose-related ( $10 \mathrm{mg}$ vs. $15 \mathrm{mg}$ weekly) effect of methotrexate (MTX) therapy on pulmonary function test (PFT) measured at baseline (1), after 6 months of therapy (2) and at termination of MTX (3). A significant improvement of $10 \%$ was observed between groups (10 $\mathrm{mg}$ vs. $15 \mathrm{mg}$ weekly) for DLCO after six months of MTX therapy

\begin{tabular}{|c|c|c|c|c|c|}
\hline \multirow{2}{*}{ Variable } & \multicolumn{2}{|c|}{10 mg weekly ( $N=31$ ) } & \multicolumn{2}{|c|}{15 mg weekly ( $N=18$ ) } & \multirow{2}{*}{$\mathbf{p}$} \\
\hline & Mean & \pm SD & Mean & $\pm S D$ & \\
\hline (1)DLCO \%pred & 65.48 & 16.2 & 68.38 & 14.6 & NS \\
\hline (1)TLC \% pred & 86.00 & 15.7 & 83.14 & 22.2 & NS \\
\hline (1)FVC \%pred & 79.30 & 16.7 & 78.91 & 15.5 & NS \\
\hline (1)FEV $1 \%$ pred & 71.98 & 20.8 & 67.57 & 17.3 & NS \\
\hline (2)DLCO \%pred & 63.15 & 16.4 & 73.27 & 12.7 & 0,030 \\
\hline (2)TLC \% pred & 88.67 & 16.4 & 91.52 & 20.8 & NS \\
\hline (2)FVC \%pred & 82.31 & 21.1 & 88.04 & 15.0 & NS \\
\hline (2)FEV $\%$ pred & 73.09 & 22.4 & 72.49 & 17.5 & NS \\
\hline (3)DLCO \%pred & 64.63 & 17.1 & 74.25 & 16.5 & NS \\
\hline (3)TLC \% pred & 88.54 & 14.9 & 91.57 & 21.3 & NS \\
\hline (3)FVC \%pred & 83.07 & 20.6 & 89.88 & 15.2 & NS \\
\hline (3)FEV 1 \%pred & 73.7 & 22.2 & 72.92 & 19.4 & NS \\
\hline MTX responders & $13(46 \%)$ & & $12(65 \%)$ & & \\
\hline MTX non-responders & $18(54 \%)$ & & $6(35 \%)$ & & \\
\hline
\end{tabular}

Sixteen patients (32\%) terminated the MTX therapy after six months for various reasons: subjective intolerance $(\mathrm{N}=2)$, adverse effects of MTX therapy $(\mathrm{N}=3)$, no improvement in any of analysed clinical parameters $(\mathrm{N}=5)$, or progression of sarcoidosis on treatment $(\mathrm{N}=6)$. Nineteen patients (38\%) were treated for longer than six months but did not complete the 24-month protocol because of the following: stabilisation of sarcoidosis for two consecutive control visits $(\mathrm{N}=13)$, adverse effects or subjective intolerance $(\mathrm{N}=6)$. One patient was excluded from the study after six months of therapy because of non-compliance. For the further statistical analysis of treatment effectiveness 49 patients were included (Fig. 3) 
Table 3. Characteristics of lung function and exercise performance before and after MTX treatment in whole cohort

\begin{tabular}{|c|c|c|c|}
\hline Variable & $\begin{array}{c}\text { Baseline values } \\
\text { ( } N=49 / 50-\text { one patient not included) }\end{array}$ & $\begin{array}{l}\text { After treatment } \\
(N=49 / 50)\end{array}$ & $\mathbf{p}$ \\
\hline $\mathrm{DLCO}[\mathrm{mmol} / \mathrm{min} / \mathrm{kPa}]$ & $6.38 \pm 1.8$ & $6.54 \pm 2.2$ & $0.70 \mathrm{NS}$ \\
\hline DLCO (\%pred) & $66.52 \pm 15.6$ & $67.48 \pm 16.9$ & $0.77 \mathrm{NS}$ \\
\hline TLC (L) & $5.15 \pm 1.1$ & $5.43 \pm 1.2$ & $0.21 \mathrm{NS}$ \\
\hline TLC (\%pred) & $84.97 \pm 18.2$ & $89.65 \pm 17.4$ & $0.19 \mathrm{NS}$ \\
\hline $\mathrm{FVC}(\mathrm{L})$ & $3.35 \pm 0.9$ & $3.52 \pm 1.05$ & $0.39 \mathrm{NS}$ \\
\hline FVC (\%pred) & $79.16 \pm 16.1$ & $85.84 \pm 19.2$ & $0.063 \mathrm{NS}$ \\
\hline $\mathrm{FEV}_{1}(\mathrm{~L})$ & $2.42 \pm 0.8$ & $2.47 \pm 0.8$ & $0.75 \mathrm{NS}$ \\
\hline FEV $1 \%$ pred) & $70.39 \pm 19.5$ & $73.45 \pm 21.0$ & $0.45 \mathrm{NS}$ \\
\hline $\mathrm{FEV}_{1} \% \mathrm{FVC}$ & $0.77 \pm 11.8$ & $0.68 \pm 12.5$ & $0.34 \mathrm{NS}$ \\
\hline $\mathrm{SaO}_{2} \min (\%)$ & $91.0 \pm 3.8$ & $92.38 \pm 3.6$ & 0.043 \\
\hline$\Delta \mathrm{SaO}_{2}(\%)$ & $5.27 \pm 3.2$ & $4.09 \pm 2.9$ & 0.048 \\
\hline Distance $[\mathrm{m}]$ & $531 \pm 106$ & $546 \pm 106$ & $0.33 \mathrm{NS}$ \\
\hline Distance (\%pred) & $87.20 \pm 11.0$ & $92.3 \pm 11.6$ & $0.12 \mathrm{NS}$ \\
\hline Exercise dyspnoea (Borg score, points) & $1.22 \pm 1.9$ & $0.75 \pm 1.3$ & $0.35 \mathrm{NS}$ \\
\hline
\end{tabular}

Baseline characteristics of the treatment cohort (49 patients) according to the response to MTX are presented in Table 3. Looking for the impact of MTX on different clinical indices in the whole cohort, a significant improvement was observed for minimal $\mathrm{SaO}_{2}(\%)$ measured during exercise $(\mathrm{p}=0.043)$ and for $\Delta \mathrm{SaO}_{2}(\%)(\mathrm{p}=0.048)$ (Tab. 3). During the MTX treatment of the whole cohort no significant increase of any of analysed PFT parameters was observed (Tab. 3, Fig. 2).

Patients with objective benefits from therapy ("MTX responders" group) received significantly higher total dose of MTX $(919.6 \pm 376 \mathrm{mg}$ vs. $512.5 \pm 380 \mathrm{mg}, \mathrm{p}=0.0004$ ) and were treated longer $(76.8 \pm 30.6$ weeks vs. $44.04 \pm 29.7$ weeks, $p=$ 0.001) (Tab. 4). They also had significantly lower TLC and FVC initial values compared to "MTX non-responders" (Tab. 4). Other mean initial PFT values were also lower in the "MTX responders" group compared to the "MTX non-responders" group although the difference did not reach the statistical significance. No other significant differences between groups ("MTX responders" vs. "MTX non-responders") were observed in any of analysed baseline parameters (Tab. 4), including previous GCS therapy.

Radiological improvement after MTX therapy was revealed in 28 (56\%) patients. In all those cases partial regression of disseminated changes were observed, without impact on radiological signs of fibrosis. In three cases radiological improvement was not associated with significant functional amelioration. In all patients with significant improvement in at least one PFT parameter a radiological improvement of CXR/lungCT was observed. No normalisation of radiological picture was observed in any case.

All patients with extrathoracic sarcoidosis who responded to MTX therapy (by the significant improvement in PFT) experienced partial or total extra thoracic lesion reduction. The most sensitive to MTX therapy were skin lesions ( $>50 \%$ reduction from baseline changes).

In one patient with advanced systemic lymph nodes sarcoidosis that accompanied pulmonary lesions the progression of extrathoracic sarcoidosis during MTX treatment led to premature MTX withdrawal.

In 17 patients (34\%) GCS treatment following MTX withdrawal was necessary because of disabling disease. In all those cases sarcoidosis improved on steroids during the six months of follow-up.

In the "MTX responders" group FVC\%pred and TLC\%pred measured after therapy reached the values within the normal range (respectively: FVC\%pred: $73.6 \pm 12.8$ before treatment vs. 89.1 \pm 17.6 after treatment, $\mathrm{p}<0.0001$ and TLC\%pred: $77.9 \pm 12.7$ before treatment vs. $87.9 \pm 13.4$ after treatment, $\mathrm{p}<0.0001$ ) (Tab. 5). 
Table 4. Baseline characteristics of treatment cohort in relation to treatment effectiveness (responders vs. non-responders to methotrexate)

\begin{tabular}{|c|c|c|c|c|}
\hline $\begin{array}{l}\text { Variable } \\
\text { Mean } \pm \text { SD }\end{array}$ & $\begin{array}{l}\text { All patients } \\
(\mathrm{N}=49)\end{array}$ & $\begin{array}{l}\text { MTX responders } \\
(\mathrm{N}=25)\end{array}$ & $\begin{array}{l}\text { MTX non-responders } \\
\quad(\mathrm{N}=24)\end{array}$ & $P$ value \\
\hline Age at start of therapy (yrs) & $45.55 \pm 8.9$ & $45.76 \pm 8.9$ & $45.33 \pm 9.0$ & $0.87 \mathrm{NS}$ \\
\hline Male sex, N (\%) & $28(57.1)$ & $16(64.0)$ & $12(50.0)$ & $0.55 \mathrm{NS}$ \\
\hline $\mathrm{BMI}\left[\mathrm{kg} / \mathrm{m}^{2}\right]$ & $27.60 \pm 4.5$ & $27.86 \pm 4.8$ & $27.29 \pm 4.2$ & $0.67 \mathrm{NS}$ \\
\hline MTX total dose [mg] & $720.20 \pm 427$ & $919.60 \pm 376$ & $512.50 \pm 380$ & 0.0004 \\
\hline Dose/BMI [mg/kg/m²] & $27.33 \pm 16.2$ & $34.06 \pm 15.3$ & $19.33 \pm 13.7$ & 0.0009 \\
\hline Duration of treatment (weeks) & $60.75 \pm 34.1$ & $76.80 \pm 30.6$ & $44.04 \pm 29.7$ & 0.001 \\
\hline \multicolumn{5}{|l|}{ Smoking } \\
\hline Current, N (\%) & $2(4.35)$ & $0(0)$ & $2(9.09)$ & $0.21 \mathrm{NS}$ \\
\hline Former, N (\%) & $23(50.0)$ & $11(45.83)$ & $12(54.55)$ & $0.21 \mathrm{NS}$ \\
\hline Disease duration & $12.34 \pm 20.49$ & $12.14 \pm 21.1$ & $12.56 \pm 20.3$ & $0.91 \mathrm{NS}$ \\
\hline Bronchiectases, N (\%) & $17(38.64)$ & $9(42.86)$ & $8(34.78)$ & $0.58 \mathrm{NS}$ \\
\hline Ground glass opacities, N (\%) & $8(17.78)$ & $3(13.64)$ & $5(21.74)$ & $0.48 \mathrm{NS}$ \\
\hline Previous prednisone therapy, $\mathrm{N}(\%)$ & $41(82)$ & $21(80.00)$ & $20(79.17)$ & $0.94 \mathrm{NS}$ \\
\hline \multicolumn{5}{|l|}{ PFT (\%pred) } \\
\hline $\mathrm{FEV}_{1}$ & $70.39 \pm 19.5$ & $66.26 \pm 16.4$ & $73.14 \pm 21.1$ & 0.702 NS \\
\hline FVC & $79.16 \pm 16.1$ & $73.65 \pm 12.8$ & $83.42 \pm 16.7$ & 0.025 \\
\hline TLC & $84.97 \pm 18.2$ & $77.95 \pm 12.7$ & $91.61 \pm 20.6$ & 0.007 \\
\hline DLCO & $66.52 \pm 15.6$ & $64.37 \pm 14.8$ & $67.63 \pm 15.8$ & $0.46 \mathrm{NS}$ \\
\hline $\mathrm{FEV}_{1} \% \mathrm{FVC}$ & $77 \pm 11.8$ & $71.99 \pm 11.4$ & $69.92 \pm 12.5$ & $0.53 \mathrm{NS}$ \\
\hline Airflow limitation, N (\%) & $18(36.7)$ & $9(36.0)$ & $9(37.5)$ & $0.91 \mathrm{NS}$ \\
\hline \multicolumn{5}{|l|}{ 6MWT } \\
\hline $\mathrm{SaO}_{2} \min (\%)$ & $91 \pm 3.8$ & $91.2 \pm 3.0$ & $90.6 \pm 4.5$ & 0.86 NS \\
\hline$\Delta \mathrm{SaO}_{2}(\%)$ & $5.27 \pm 3.2$ & $5.21 \pm 3.0$ & $5.52 \pm 3.4$ & $0.81 \mathrm{NS}$ \\
\hline Distance $[\mathrm{m}]$ & $531 \pm 106$ & $570.7 \pm 91$ & $525.2 \pm 118$ & $0.93 \mathrm{NS}$ \\
\hline \multicolumn{5}{|l|}{ Dyspnoea (Borg score, points) } \\
\hline Before exercise & $0.11 \pm 0.43$ & $0.21 \pm 0.59$ & $0.00 \pm 0.0$ & $0.469 \mathrm{NS}$ \\
\hline After exercise & $1.22 \pm 1.9$ & $1.56 \pm 2.12$ & $0.91 \pm 1.64$ & $0.463 \mathrm{NS}$ \\
\hline Extrapulmonary involvement, N (\%) & $36(73.47)$ & $17(68.00)$ & $19(79.17)$ & $0.37 \mathrm{NS}$ \\
\hline Skin, N (\%) & $10(20.41)$ & $4(16.00)$ & $6(25.00)$ & $0.43 \mathrm{NS}$ \\
\hline Lymph nodes, N (\%) & $18(37.50)$ & $8(32.00)$ & $10(43.48)$ & $0.41 \mathrm{NS}$ \\
\hline Liver, N (\%) & $9(19.55)$ & $4(16.00)$ & $5(22.73)$ & $0.55 \mathrm{NS}$ \\
\hline Spleen, N (\%) & $19(38.78)$ & $12(48.00)$ & $7(29.17)$ & $0.17 \mathrm{NS}$ \\
\hline Others, N (\%) & $7(14.29)$ & $2(8.00)$ & $5(20.83)$ & $0.20 \mathrm{NS}$ \\
\hline $\begin{array}{l}\text { Multiple (at least } 2 \text { organs) involvement, } \\
\mathrm{N}(\%)\end{array}$ & $21(42.86)$ & $8(32.00)$ & $13(54.17)$ & $0.11 \mathrm{NS}$ \\
\hline
\end{tabular}

In the "MTX non-responders" group the most significant deterioration from baseline values during the treatment were observed for DLCO\%pred $(67.6 \pm 15.8$ vs. $61.1 \pm 16.4, \mathrm{p}=$ $0.003)$ and $\mathrm{FEV}_{1} \%$ pred $(73.1 \pm 21.1$ vs. $68.8 \pm$ 21.6, $\mathrm{p}=0.022$ ) (Fig. 4).
After treatment the only significant difference in PFT between groups was noted for DLCO. Diffusing capacity was significantly higher in "MTX responders" vs. "MTX non-responders" (Tab. 5).

From the total group of 50 patients, 11 (22\%) stopped the treatment because of adverse effects 
Table 5. The results of pulmonary function test before and after methotrexate treatment, in relation to treatment effectiveness (responders vs. non-responders to methotrexate)

\begin{tabular}{lcccc}
\hline \multirow{2}{*}{$\begin{array}{l}\text { Variable } \\
\text { Mean } \pm \text { SD }\end{array}$} & \multicolumn{2}{c}{$\begin{array}{c}\text { MTX responders } \\
\text { (N = 25) }\end{array}$} & \multicolumn{2}{c}{$\begin{array}{c}\text { MTX non-responders } \\
\text { (N = 24) }\end{array}$} \\
\cline { 2 - 5 } & Before treatment & After treatment & Before treatment & After treatment \\
\hline FEV $1 \%$ pred) & $66.26 \pm 16.4$ & $78.15 \pm 19.7$ & $73.14 \pm 21.1$ & $68.75 \pm 21.6$ \\
FVC (\% pred) & $73.65 \pm 12.8^{*}$ & $89.08 \pm 17.6$ & $83.42 \pm 16.7^{*}$ & $81.92 \pm 19.8$ \\
TLC (\% pred) & $77.95 \pm 12.7^{* *}$ & $87.88 \pm 13.4$ & $91.61 \pm 20.6^{* *}$ & $91.50 \pm 20.9$ \\
DLCO (\% pred) & $64.37 \pm 14.8$ & $74.93 \pm 15.8^{* * *}$ & $67.63 \pm 15.8$ & $61.12 \pm 16.4^{* * *}$ \\
FEV $\%$ FVC & $71.99 \pm 11.4$ & $69.80 \pm 9.5$ & $69.92 \pm 12.5$ & $67.59 \pm 15.0$ \\
\hline Significant differences between groups were found for FVC and TLC before treatment $\left.~^{*} \mathrm{p}=0.025_{*}^{* *} \mathrm{p}=0.007\right)$ and for DLC0 after treatment $\left(^{* * *} \mathrm{p}=0.0042\right)$
\end{tabular}

Significant differences between groups were found for FVC and TLC before treatment $\left({ }^{*} p=0.025,{ }^{* *} p=0.007\right)$ and for DLCO after treatment $\left({ }^{* * *} p=0.0042\right)$

of MTX. Gastrointestinal (GI) problems (nausea, stomachache) and malaise, without any laboratory abnormalities, were reported by five patients and occurred most often within the first three months of therapy leading to withdrawal in two cases. The most frequently reported side effects were mild hepatic abnormalities (in 10 patients, $20 \%$ ). In those cases, none of important organ dysfunction due to therapy was diagnosed. Four patients had to quit therapy because of the elevation of hepatic enzymes or bilirubin. In one case hepatic abnormalities were associated with mild leukopenia (after 15 months of treatment) and in one case with infection of varicella zoster (patient quit MTX treatment after five months of therapy). None of the patients experienced severe hepatic function decline, and liver function recovered in all patients after therapy discontinuation.

In patients with hepatic sarcoidosis confirmed with liver biopsy, no significant laboratory changes in hepatic function were observed during treatment.

No important anaemia or other haematological disorders were noticed in our cohort.

Infections were reported in four cases (8\%) (including one case that was associated with hepatic abnormalities) and were the reason to resign from treatment. In two cases tuberculosis was confirmed with positive cultures. In those two cases the radiological progression of disseminated changes were diagnosed during MTX treatment, and patients underwent all diagnostic procedures to elucidate the nature of deterioration of CXR. In one case a suspicion of pulmonary tumour necessitated verification with an open lung biopsy, which showed tuberculoma. In the second case the BAL fluid cultures were BK positive. Patients completed the six-month antituberculosis (anti-TB) regimen. During this anti-TB treatment important radiological and functional progression of sarcoidosis was observed.
One patient was admitted to hospital after three months of therapy because of severe dyspnoea, cough, and hypoxaemia. His CXR was similar to baseline, with no radiological progression of disseminated changes or fibrosis on chest HRCT scans. His serology was positive for Mycoplasma and Chlamydia antibodies. MTX therapy was stopped and the patient received antibiotics, steroids, and oxygen therapy and recovered within two weeks. Steroids were continued for his pulmonary sarcoidosis with significant improvement in six months of follow up.

In two patients, during the routine sputum check, Aspergillus fumigatus colonies were found with no signs or symptoms of allergic or systemic, invasive aspergillosis. In those patients the reason for discontinuation for treatment was lack of efficacy of MTX. There were no patients with a fatal outcome while receiving MTX therapy.

For the whole group no significant differences were observed before and after treatment in the majority of safety parameters. The only significant differences between the initial and post-treatment values were noticed for alanine aminotransferase (ALT), but the mean ALT value after therapy for the whole cohort $(33.96 \pm 25.74 \mathrm{U} / \mathrm{L}, \mathrm{p}=0.043)$ was within normal values.

\section{Discussion}

This was an prospective single-centre real-life open label study of methotrexate as a monotherapy in chronic, progressive pulmonary sarcoidosis. Most patients had been treated previously with GCS, without maintained improvement or with important adverse effects. In our study the treatment with MTX showed objective pulmonary benefits in 55\% of the treated cohort. The disease duration before initiating MTX therapy, high rate of extrapulmonary sarcoidosis, PFT deterioration 


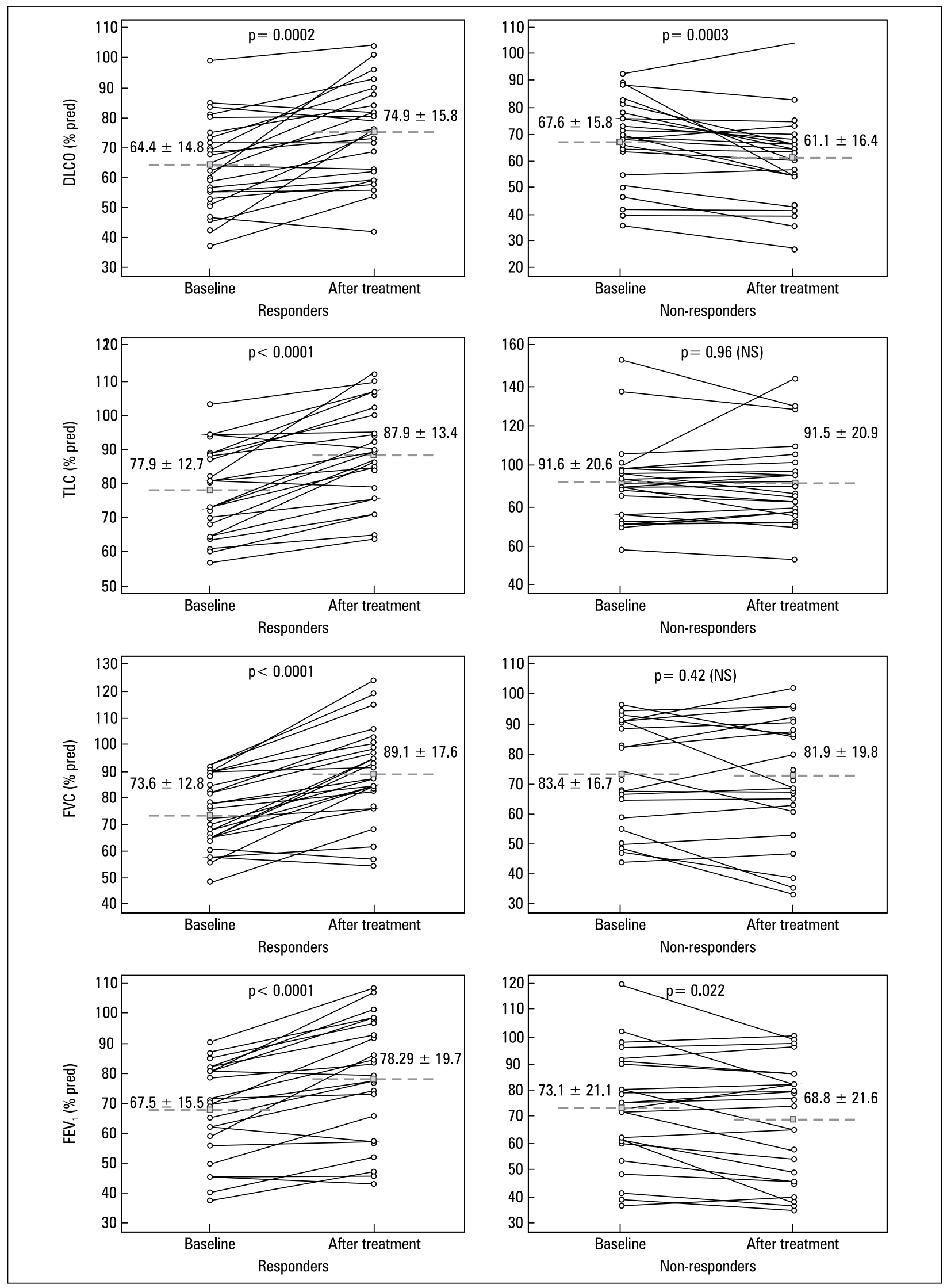

Figure 4. Individual results of MTX treatment on PFT parameters in "Responder" and "Non-responder" groups 
before enrolment and previous steroid treatment confirm that our cohort comprised patients with chronic and disabling sarcoidosis. Statistical analysis of PFT results comparing the initial visit values to baseline values showed significant deterioration of $\mathrm{FEV}_{1}, \mathrm{FVC}$, and DLCO. This may reflect the active inflammatory process and justify the indication for therapy.

We observed a dose-related effect of MTX in our cohort. MTX total dose was almost double in the "MTX responders" group compared to the "non-responders" group, and that was confirmed by adjustment to the BMI. Our study protocol allowed MTX therapy to be started with either dose of $10 \mathrm{mg}$ or $15 \mathrm{mg}$ weekly, without any precise criteria justifying this decision, besides clinical evaluation. This is a weak point of the study and makes the interpretation of the dose relation effectiveness very difficult. The MTX dose of $10 \mathrm{mg}$ per week was adapted from a randomised controlled study showing that sarcoidosis patients without previous treatment, who took MTX $10 \mathrm{mg}$ weekly, required significantly lower doses of glucocorticosteroids than patients taking placebo [7]. In this study MTX was given as a steroid-sparing agent. We presumed that in individual situations (e.g. obesity, need for high dose of steroids in the past to control the disease) MTX given as a monotherapy should be administered in a higher dose. There are no studies comparing higher and lower dosages of MTX to provide the best treatment effect with acceptable safety profile in sarcoidosis, but the dose-dependent efficacy was proven in rheumatoid arthritis patients $[17,18]$. Our treatment protocol was adapted from recommendations for the use of MTX in rheumatic disorders and supplemented with expert opinions $[8,12,13]$. Recently published multinational recommendations for the use of MTX in sarcoidosis suggest that an initial dose of oral MTX between 5-15 mg weekly, without indicating potential candidates for the dose of 15 $\mathrm{mg}$ [10]. The escalation of initial dose to 10-15 mg per week may be considered after eight weeks in cases presenting insufficient response and acceptable safety profile.

The choice of the treatment dose in our protocol was based on physicians' experience and was adapted to individual patients. The risks and benefits of higher dose of MTX were explained to the patient before the final decision was made. In our study $34 \%$ of patients agreed to be treated with the dose of $15 \mathrm{mg}$ weekly. In this group we observed significantly higher rate of 24-month treatment achievement, a higher rate of "MTX responders" patients, and a lower rate of patients who stopped the therapy after six months. All the infections that led to premature termination of therapy were diagnosed in individuals treated with $10 \mathrm{mg}$ weekly. It seems that MTX dose of $15 \mathrm{mg}$ weekly is safe and might be more effective than $10 \mathrm{mg}$ weekly, independently of BMI.

The length of therapy was significantly longer in "MTX responders" vs. "non-responders". This might be explicable by the treatment protocol, according to which the MTX therapy was terminated before the planned 24 months because of very different reasons (e.g. stabilisation of the disease documented by two consecutive visits, side effects, subjective wish of the patient). By the end of therapy we did not know who met the criteria of the "MTX responders" group. The statistical analysis was performed retrospectively to determine patients who had objective response to MTX therapy. PFT results seemed to be the most valuable outcome parameters for pulmonary sarcoidosis. The lack of a precise end-point for therapy, which would allow a reliable conclusion to be drawn about the relation between dose and treatment duration and clinical effect of therapy, is a weak part of the study protocol. In some patients the clinical effect of the therapy might be reached earlier, and some patients may need to be treated longer to achieve the clinical improvement. This is a point that needs further exploration.

The monotherapy with MTX should be considered from different aspects: the indications for therapy, the effectiveness, and the safety.

The decision to treat sarcoid patients is usually difficult. In most cases the disease can resolve spontaneously or become self-limited. In those situations the pharmacotherapy might cause adverse effects that would not be balanced by the benefit from the treatment [12, 13, 19, 20].

The prognostic parameters and predictors of remission in sarcoidosis are not evident, especially for the disease that lasts over two years. The potential group of patients with pulmonary sarcoidosis that could benefit from medication is not defined. Therefore, there is no precise evidence about who should be treated [21, 22]. In order to minimise the confounding issue of spontaneous remission, in our study protocol patients demonstrating progressive radiological and/or physiological changes were eligible, according to the definition of chronic pulmonary sarcoidosis adapted from WASOG Task Force and experts' opinions $[11,12]$.

Most physicians involved in care of sarcoid patients admit that patients with disabling symp- 
tomatic disease, prolonged course, and evidence of progressive functional damage of affected organs are potential candidates for pharmacotherapy. Moderate-to-severe dyspnoea at presentation is an independent predictor of the need for systemic therapy for more than two years after diagnosis [23]. The presence of pulmonary fibrosis is associated with chronic disease and worse clinical outcome [24]. Defining chronic progressive sarcoidosis on the basis of PFT deterioration, exercise capacity reduction, and progression of radiological changes [11-13] means that the treated group will always be heterogeneous. In the study protocol we did not include any laboratory criteria for diagnosing active disease; however, we believe that it is important to do so in the future. We are convinced that the indications for treatment should include the assessment of disease activity, based also on assessment other than radiological and/or functional.

An absolute indication for treatment includes the manifestations of the disease that are life or organ threatening. About $20-25 \%$ of sarcoid patients will have a permanent decrease in lung function, about $10 \%$ will develop pulmonary fibrosis, and $5-10 \%$ of patients will die from respiratory failure or cor pulmonale [25-27]. Glucocorticosteroids are considered the first-line treatment, but this is an imperfect solution. This is a potentially toxic therapy with a high rate of adverse effects. It influences the long-term prognosis in individual patients and may impair quality of life, more than the disease itself, especially in young people. In some patients GCS are contraindicated even in a severe case of sarcoidosis because of possible complications. What is more, this treatment does not cure the sarcoidosis, so one can expect recurrence of disease with drug withdrawal. The next issue are refractory cases who need other treatment solutions.

A systematic literature search shows that randomised controlled trials (RCT) supporting the use of MTX in sarcoidosis are very limited $[10,13]$. There is a lack of controlled studies comparing the efficacy and safety of GCS treatment vs. MTX monotherapy. It is more than likely that no ethics board would approve such a study while GCS therapy is recommended by experts' guidelines WASOG/ERS/ATS as a first-line treatment in sarcoidosis [11]. On the other hand, in rheumatoid arthritis (RA) and other systemic immune mediated disorders, MTX has proven, from several RCTs and high-quality cohort studies, to be the best therapeutic option to modify the natural course of the disease [2, 14, 28, 29].
In those diseases GCS was the first-line treatment in the past. It has to be proven that MTX is a safe and efficient treatment option before considering it as a first-line therapy for sarcoidosis.

As well as in other diseases (i.e. juvenile rheumatoid arthritis, asthma), there were "responders" and "non- responders" to low-dose MTX $[30,31]$. The decision to qualify the patient to the "responders" vs. "non-responders" group based on the PFT assessment was made retrospectively, with the intention of searching for an objective measure of efficacy. Progressive pulmonary sarcoidosis was the indication for MTX treatment in our cohort, so the PFT assessment at the end of therapy seemed to be the most logical, credible, objective outcome parameter.

In this first analysis of collected data we focused on the impact of MTX treatment on lung function, independently of the radiological picture. The lack of a recognised radiological objective method that would allow for the comparative study of the radiological picture before and after treatment makes the objective quantification of radiological changes very difficult. For extrapulmonary sarcoidosis we acknowledge that there is no standardised or validated assessment of treatment response. MTX therapy in previously published case reports was indicated mostly for extrapulmonary sarcoidosis [7-9]. The heterogeneity of the treatment group makes the clinical evaluation of effectiveness of therapy very difficult. Some patients left the study because of subjective intolerance after six months of therapy. We have observed that some patients improved within six months and remained stable for the further months of treatment while others needed more than six months of therapy to experience an improvement. This explains why some individuals were treated for more than six months but stopped therapy before the scheduled 24-month protocol. In two cases, after the initial PFT improvement, infectious complications developed during the observational time and led to premature discontinuation of therapy. The PFT results deteriorated because of concomitant infection, not because of lack of efficacy of treatment, but the patients were classified as "non-responder".

In our cohort $55 \%$ of patients experienced a significant improvement in at least one of PFT parameter $\left(\mathrm{FEV}_{1}, \mathrm{FVC}\right.$, TLC, or DLCO). This beneficial effect of MTX therapy on lung function was already confirmed in previous studies, even in patients who were treated because of extrapulmonary indications [7-9, 32]. A comparison of the PFT parameters in our cohort before and 
after treatment revealed the significant amelioration of each analysed parameter in the "MTX responders" group.

Patients who benefited from MTX therapy were those with initially impaired volume and capacity parameters. Patients who responded well to treatment had significantly lower TLC and FVC initial values compared to "MTX non -responders". The "complete response" was seen only for FVC and TLC, and the most "sensitive" parameter for therapy was FVC.

Additionally, DLCO value after treatment in the groups of "MTX responders" vs. "non-responders" was shown to be significantly higher in the "MTX responders" group. It has been proven that MTX shows an anti-inflammatory effect, suppressing alveolar macrophage cytokine release and lymphocytic alveolitis [33]. The DLCO improvement after treatment may reflect an anti-inflammatory activity of MTX if we look at the DLCO impairment as an indirect sign of alveolar inflammation [34].

A similar impact of MTX therapy on PFT parameters was noted by Vorselaars [9]. The authors observed an improvement ( $>10 \%$ ) of at least one of the parameters $\left(\mathrm{FEV}_{1}, \mathrm{VC}\right.$, and DLCO) in $57 \%$ of patients, independently of treatment indications (patients received the steroid-sparing therapy MTX or azathioprine because of pulmonary or extrapulmonary indication) and with no significant differences between azathioprine and methotrexate groups (145 patients received MTX as a steroid sparing agent). The important difference between our study group and Vorselaars cohort is that in our group MTX was the single agent in all 49 patients while in Vorselaars cohort only 13 patients out of 200 received MTX as a monotherapy.

Other authors have reported sarcoidosis improvement in $66 \%$ of patients treated with MTX. Lower and Baughman used methotrexate $(10 \mathrm{mg}$ weekly) as a steroid-sparing agent for over two years in 50 patients with intrathoracic sarcoidosis. They observed a $>10 \%$ of VC improvement in 22 cases (vs. 28 non-responders) [8]. The improvement of PFT in the Vorselaars [9] and Lower [8] cohort might be attributable to combined therapy. The authors did not compare the effects of treatment in groups receiving MTX monotherapy vs. MTX combined with steroid therapy.

Until now, no study has focused on impact of MTX therapy on exercise tolerance. Baughman looked at the Borg dyspnoea scale during exercise and noticed an insignificant decrease for the MTX group. In that study, MTX was a steroid-sparing agent that was compared to placebo and proved to be effective in reducing the prednisone dosage [7].

In interstitial lung diseases 6MWT has proven to be a useful, reliable tool for both predicting mortality and monitoring response to therapy. In the Baughman study on 6MWT in sarcoidosis the walk distance depended on FVC and minimal oxygen saturation [35]. Although the MTX therapy had no impact on the 6MWT distance in our cohort, one may expect a positive influence of treatment on the exercise ability in a larger group of sarcoid patients with improvement of FVC and minimal oxygen saturation after treatment. Both were shown to improve in our patients after MTX therapy. The assessment of 6MWT in our studied group revealed a significant improvement in objective parameters: the minimal $\mathrm{SaO}_{2}$ during exercise significantly improved, and the degree of desaturation during exercise significantly decreased after treatment for the whole group. Those parameters seem to change independently of PFT indices because we did not find any significant differences in exercise ability indices between the "MTX responders" and the "MTX non-responders" group. We suppose that MTX might improve the exercise ability by its influence also on parameters other than FVC, which has been proven to be equally important. Baughman and Lower concluded from their study on 6MWT in sarcoidosis that 6MW distance depends on multiple factors, not only pulmonary function [35]. We did not observe any significant impact of MTX therapy on Borg dyspnoea scale or on 6MWT distance for the whole group, even if comparing "MTX responders" vs. "MTX non-responders" before and after treatment.

When comparing the PFT results at different study control visits between patients who received the "first-line MTX therapy" to those treated by GCS in the past, we did not find any significant differences at recruitment, baseline, and during MTX therapy. No conclusions can be drawn from this analysis because the group of "first-line" MTX treatment was relatively small.

MTX therapy was shown to be safe in our cohort. Only in two cases, the subjective intolerance led to premature MTX withdrawal. A total of 11 patients $(22 \%)$ stopped the therapy because of AE. One patient experienced varicella zoster and quit MTX treatment after five months of therapy.

This dropout is similar to that described by Vorselaars (37 patients, 18.5\%) and the Higher to Lower study (9.5\%) and to the Vucinic study (no one had to stop MTX therapy because of AE in six months of treatment) [8, 9, 32]. 
The problems of interpretation of abnormal laboratory findings in sarcoidosis arise from difficulties in separating the drug-related suppressive effects on the bone marrow or hepatic function and those caused by the disease.

Serial studies of patients with sarcoidosis have shown that lymphopaenia is the most common abnormality, significant anaemia is seen in $20 \%$ of cases, and leukopaenia occurs in $10 \%$ of cases. Those abnormalities are the result of the presence of bone marrow granulomas or toxic effects of different cytokine release in active sarcoidosis [36]. We observed only one case of leukopaenia that led to MTX discontinuation with no important reduction of neutrophil count. The low incidence of haematological side effects in our cohort might be partially attributable to the fact that the MTX treatment was applied just in patients with normal total blood count and no evidence of marrow disruption. Moreover, folic acid administration was higher (5 mg daily) compared to other studies [7-9].

Liver toxicity from MTX in sarcoidosis is not easily predicted on the basis of any liver function tests [37, 38]. The presence of liver disease due to sarcoidosis is not a contraindication to treatment with MTX. In some cases with liver involvement from sarcoidosis, MTX therapy can improve the liver function tests. One of the appreciated guidelines is to re-evaluate patients with liver biopsy after each gram of cumulative therapy if the continuation with MTX is recommended [37].

In our study we decided to perform the liver biopsy before MTX treatment to determine the definitive diagnosis of hepatic abnormalities [39]. In one patient hepatitis $\mathrm{C}$ (HCV) infection was discovered. He received a regimen with $10 \mathrm{mg}$ of MTX/week that was approved by a gastroenterologist. No impairment of liver function during nine months of treatment was observed. Treatment was terminated because of advanced pulmonary fibrosis with minimal active disease, stable CXR image during treatment, lack of expected improvement in PFT, and active HCV infection. Interferon therapy for HCV infection was planned, but severe progression of sarcoidosis after MTX withdrawal was diagnosed as an important contraindication for such treatment.

The MTX therapy proved to be safe in patients with initial laboratory impairment of hepatic function of different origin (including steatosis), hepatic sarcoidosis confirmed by biopsy, and in patients with active HCV infection. In one patient alcohol abuse was the cause of liver test abnormalities and led to treatment discontinuation.
We confirmed that the most common side effects of MTX were minor hepatic laboratory abnormalities that usually resolve. Most of our patients experienced an increase in serum ALT and bilirubin concentrations, as was described by other researchers $[2,40]$. Lower et al. observed that the mean alkaline phosphatase (ALP) concentration is significantly higher in patients with sarcoidosis and MTX toxicity (confirmed by hepatic biopsy), but they did not find any liver function test result that would predict MTX toxicity [8]. We did not observe in our cohort any significant changes in ALP concentrations during MTX therapy or after drug withdrawal because of mild hepatotoxicity.

The most serious reactions we noted were lower respiratory tract infections, including two cases of tuberculosis (TB). Evidence of a relation between sarcoidosis and mycobacterial infections has been provided by long-term clinical studies [41]. The follow-up of M. tuberculosis DNA-positive sarcoid patients showed that they are not at greater risk of developing tuberculosis, even on steroid therapy [42]. In both TB patients several sputum and BAL fluid cultures were negatives for Bacilli Koch (BK) before starting the MTX treatment. TB developed during immunosuppressive therapy with MTX and was the reason for drug withdrawal. Although successfully treated with an anti-TB regimen, both patients experienced serious sarcoidosis progression after MTX withdrawal with PFT deterioration that needed steroid therapy. We would advise monitoring of all immunosuppressed patients closely and consideration of TB infection even if mild clinical symptoms occur.

\section{Conclusions}

MTX as a single agent in the treatment of sarcoidosis has proven to be a safe and effective steroid alternative. Selected sarcoid patients with chronic progressive sarcoidosis experience definite PFT improvement after MTX treatment. There is a need to define predictors of MTX treatment effectiveness.

\section{Conflicts of interests}

The authors have no real or perceived conflicts of interest that relate to this paper.

\section{References:}

1. Donahue K.E., Gartlehner G., Jonas D.E. et al. Systematic review: comparative effectiveness and harms of disease-modi- 
fying medications for rheumatoid arthritis. Ann. Intern. Med. 2008; 148: 124-134.

2. Montaudie H., Sbidian E., Paul C. et al. Methotrexate in psoriasis: a systematic review of treatment modalities, incidence, risk factors and monitoring of liver toxicity. J. Eur. Acad. Dermatol. Venereol. 2011; 25: 12-18.

3. Mouterde G., Baillet A., Gaujoux-Viala C. et al. Optimizing methotrexate therapy in rheumatoid arthritis: a systematic literature review. Joint Bone Spine 2011; 78: 587-592.

4. Johns C.J., Macgregor M.I., Zachary J.B., Ball W.C. Extended experience in the long-term corticosteroid treatment of pulmonary sarcoidosis. Ann. NY Acad. Sci. 1976; 278: 722-731.

5. Johns C.J., Michele T.M. The clinical management of sarcoidosis. A 50-year experience at the Johns Hopkins Hospital. Medicine (Baltimore) 1999; 78: 65-111.

6. Baughman R.P., Lower E.E. Steroid-sparing alternative treatments for sarcoidosis. Clin. Chest Med. 1997; 18: 853-864.

7. Baughman R.P., Winget D.B., Lower E.E. Methotrexate is steroid sparing in acute sarcoidosis: results of a double blind, randomized trial. Sarcoidosis Vasc. Diffuse Lung Dis. 2000; 17: 60-66.

8. Lower E.E., Baughman R.P. Prolonged use of methotrexate for sarcoidosis. Arch. Intern. Med. 1995; 155: 846-851.

9. Vorselaars A.D., Wuyts W.A., Vorselaars V.M. et al. Methotrexate vs azathioprine in second-line therapy of sarcoidosis. Chest 2013; 144: 805-812.

10. Cremers J.P., Drent M., Bast A. et al. Multinational evidence -based World Association of Sarcoidosis and Other Granulomatous Disorders recommendations for the use of methotrexate in sarcoidosis: integrating systematic literature research and expert opinion of sarcoidologists worldwide. Curr. Opin. Pulm. Med. 2013; 19: 545-561.

11. Hunninghake G.W., Costabel U., Ando M. et al. ATS/ERS/ /WASOG statement on sarcoidosis. American Thoracic Society/ /European Respiratory Society/World Association of Sarcoidosis and other Granulomatous Disorders. Sarcoidosis Vasc. Diffuse Lung Dis. 1999; 16: 149-173.

12. Baughman R.P. Treatment of sarcoidosis. Panminerva Med. 2013; 55: 175-189.

13. Baughman R.P., Nunes H. Therapy for sarcoidosis: evidence -based recommendations. Expert Rev. Clin. Immunol. 2012; 8: 95-103.

14. Cipriani P., Ruscitti P., Carubbi F., Liakouli V., Giacomelli R. Methotrexate in rheumatoid arthritis: optimizing therapy among different formulations. Current and emerging paradigms. Clin. Ther. 2014; 36: 427-435.

15. Judson M.A., Baughman R.P., Teirstein A.S., Terrin M.L., Yeager H., Jr. Defining organ involvement in sarcoidosis: the ACCESS proposed instrument. ACCESS Research Group. A Case Control Etiologic Study of Sarcoidosis. Sarcoidosis Vasc. Diffuse Lung Dis. 1999; 16: 75-86.

16. Baughman R.P. Methotrexate for sarcoidosis. Sarcoidosis Vasc. Diffuse Lung Dis. 1998; 15: 147-149.

17. Furst D.E., Koehnke R., Burmeister L.F., Kohler J., Cargill I. Increasing methotrexate effect with increasing dose in the treatment of resistant rheumatoid arthritis. J. Rheumatol. 1989; 16: $313-320$.

18. Furst D.E. Rheumatoid arthritis. Practical use of medications. Postgrad. Med. 1990; 87: 79-92.

19. Baughman R.P., Lynch J.P. Difficult treatment issues in sarcoidosis. J. Intern. Med. 2003; 253: 41-45.

20. Baughman R.P., Lower E.E. Medical therapy of sarcoidosis. Semin. Respir. Crit. Care Med. 2014; 35: 391-406.

21. Baughman R.P., Sharma O.P., Lynch J.P., III. Sarcoidosis: is therapy effective? Semin. Respir. Infect. 1998; 13: 255-273.
22. Baughman R.P., Lower E.E. Treatment of sarcoidosis with corticosteroids: who is going to relapse and why? Sarcoidosis Vasc. Diffuse Lung Dis. 1998; 15: 19-20.

23. Baughman R.P., Judson M.A., Teirstein A. et al. Presenting characteristics as predictors of duration of treatment in sarcoidosis. QJM 2006; 99: 307-315.

24. Neville E., Walker A.N., James D.G. Prognostic factors predicting the outcome of sarcoidosis: an analysis of 818 patients. Q. J. Med. 1983; 52: 525-533.

25. Hillerdal G., Nou E., Osterman K., Schmekel B. Sarcoidosis: epidemiology and prognosis. A 15-year European study. Am. Rev. Respir. Dis. 1984; 130: 29-32.

26. Shino M.Y., Lynch Iii J.P., Fishbein M.C. et al. Sarcoidosis-associated pulmonary hypertension and lung transplantation for sarcoidosis. Semin. Respir. Crit. Care Med. 2014; 35: 362-371.

27. Baughman R.P., Winget D.B., Bowen E.H., Lower E.E. Predicting respiratory failure in sarcoidosis patients. Sarcoidosis Vasc. Diffuse Lung Dis. 1997; 14: 154-158.

28. Pavy S., Constantin A., Pham T. et al. Methotrexate therapy for rheumatoid arthritis: clinical practice guidelines based on published evidence and expert opinion. Joint Bone Spine 2006; 73: 388-395.

29. Suarez-Almazor M.E., Belseck E., Shea B., Wells G., Tugwell P. Methotrexate for rheumatoid arthritis. Cochrane Database Syst. Rev. 2000:CD000957.

30. Giannini E.H., Brewer E.J., Kuzmina N. et al. Methotrexate in resistant juvenile rheumatoid arthritis. Results of the USAUSSR double-blind, placebo-controlled trial. The Pediatric Rheumatology Collaborative Study Group and The Cooperative Children's Study Group. N. Engl. J. Med. 1992; 326: 1043-1049.

31. Marin M.G. Low-dose methotrexate spares steroid usage in steroid-dependent asthmatic patients: a meta-analysis. Chest 1997; 112: 29-33.

32. Vucinic V.M. What is the future of methotrexate in sarcoidosis? A study and review. Curr. Opin. Pulm. Med. 2002; 8: 470-476.

33. Baughman R.P., Lower E.E. The effect of corticosteroid or methotrexate therapy on lung lymphocytes and macrophages in sarcoidosis. Am. Rev. Respir. Dis. 1990; 142: 1268-1271.

34. Mostard R.L., Verschakelen J.A., van Kroonenburgh M.J. et al. Severity of pulmonary involvement and (18)F-FDG PET activity in sarcoidosis. Respir. Med. 2013; 107: 439-447.

35. Baughman R.P., Lower E.E. Six-minute walk test in managing and monitoring sarcoidosis patients. Curr. Opin. Pulm. Med. 2007; 13: 439-444.

36. Lower E.E., Smith J.T., Martelo O.J., Baughman R.P. The anemia of sarcoidosis. Sarcoidosis 1988; 5: 51-55.

37. Baughman R.P., Lower E.E. A clinical approach to the use of methotrexate for sarcoidosis. Thorax 1999; 54: 742-746.

38. Baughman R.P., Koehler A., Bejarano P.A., Lower E.E., Weber F.L. Jr. Role of liver function tests in detecting methotrexate-induced liver damage in sarcoidosis. Arch. Intern. Med. 2003; 163: 615-620.

39. Moix F.M., Raufman J.P. The role of liver biopsy in the evaluation of liver test abnormalities. Clin. Cornerstone 2001; 3: 13-23.

40. Visser K., van der Heijde D.M. Risk and management of liver toxicity during methotrexate treatment in rheumatoid and psoriatic arthritis: a systematic review of the literature. Clin. Exp. Rheumatol. 2009; 27: 1017-1025.

41. Scadding J.G. Mycobacteria and sarcoidosis. Clinical studies support link. BMJ 1993; 306: 1269-1270.

42. Fite E., Fernandez-Figueras M.T., Prats R., Vaquero M., Morera J. High prevalence of Mycobacterium tuberculosis DNA in biopsies from sarcoidosis patients from Catalonia, Spain. Respiration 2006; 73: 20-26. 